\title{
KAJIAN SINKRONISASI MESIN UTAMA DAN PROPELLER PADA KAPAL PERIKANAN PASCA REPARASI (STUDI KASUS KM. NELAYAN 2017-572)
}

\section{Study of Main Engine and Propeller Matching on Fishing Vessel After Reparation (Case Study of KM. Nelayan 2017-572)}

\author{
Ahmad Yasim $^{1, a}$, Robertoes Koekoeh Koentjoro Wibowo ${ }^{2,}$, dan Kusnindar Priohutomo ${ }^{3}$ \\ ${ }^{1}$ Teknik Konstruksi Perkapalan, Fakultas Teknik, Universitas Jember, Jl. Kalimantan No. 37, Jember, Indonesia \\ ${ }^{2}$ Teknik Mesin, Fakultas Teknik, Universitas Jember, Jl. Kalimantan No. 37, Jember, Indonesia \\ ${ }^{3}$ Balai Teknologi Hidrodinamika, Badan Pengkajian dan Penerapan Teknologi, Jl. Hidrodinamika BPPT, Surabaya, Indonesia \\ e-mail: ahmadyasim@unej.ac.id
}

Diterima: 08 April 2021; Direvisi: 21 Mei 2021; Disetujui: 27 Mei 2021

\begin{abstract}
Abstrak
Sinkronisasi antara lambung, mesin utama dan propeller pada Kapal Perikanan 5 GT pasca reparasi perlu dikaji untuk memperoleh kecepatan dan mengoptimalkan performa kapal. Penelitian diawali dengan memprediksi hambatan kapal menggunakan metode Van Oortmersen, kemudian dilakukan analisa sinkronisasi mesin dan propeller, serta tahap akhir dilakukan optimasi. Hasil penelitian didapatkan sinkronisasi mesin dan propeller memenuhi kriteria yaitu $\mathrm{T}_{\text {engine }}=\mathrm{T}_{\text {prop }}=1,98 \mathrm{kN}$, Ae $/ \mathrm{Ao}_{\min } 0,44<\mathrm{Ae} / \mathrm{Ao}_{\text {prop }} 0,55$, dan faktor load propeller $1,77<$ faktor load mesin 2,91. Lebih lanjut, diketahui bahwa kapal memiliki kecepatan 7,3 knot yang mana telah memenuhi kecepatan desain yaitu berkisar 7 - 9 knot. Optimasi engine propeller matching dilakukan dengan mengubah gearbox dari rasio 2,5 menjadi 2,2 namun hasilnya hanya menambah kecepatan sebesar 0,4 knot sehingga dinilai komposisi terbaik adalah mempertahankan mesin dan sistem penggerak kapal yang telah ada.
\end{abstract}

Kata kunci: sinkronisasi; mesin utama; propeller; kapal perikanan; faktor load

\begin{abstract}
The synchronization between the hull, main engine and propeller on the 5 GT fishing vessel after reparation needs to be studied to obtain the vessel speed and to optimize the performance if needed. The research started by predicting ship resistance using the Van Oortmersen method, then analyzing the main engine and propeller synchronization, and as the final stage is optimization. The results showed that the synchronization between the engine and propeller had met the criteria where $T_{\text {engine }}=T_{\text {prop }}=1,98 \mathrm{kN}, \mathrm{Ae} / \mathrm{Ao}_{\min } 0,44<A e / \mathrm{Ao}_{\text {prop }} 0,55$, and propeller's load factor 1,77 < engine's load factor 2,91. Furthermore, it was known that the vessel had a speed of 7,3 knots which had met the design speed range of 7-9 knot. Efforts to optimize the engine propeller matching was changing the gearbox from a ratio of 2,5 to 2,2 but the result was only increasing the speed by 0,4 knot so that the best composition is considered to maintain the existing engine and ship propulsion system.
\end{abstract}

Keywords: synchronization; main engine; propeller; fishing vessel; load factor 
Kajian Sinkronisasi Mesin Utama dan Propeller pada Kapal Perikanan Pasca Reparasi

(Studi Kasus KM. Nelayan 2017-572)

(Ahmad Yasim, Robertoes Koekoeh Koentjoro Wibowo, dan Kusnindar Priohutomo)

\section{PENDAHULUAN}

Kebijakan pemerintah untuk meningkatkan hasil perikanan tangkap melalui pengadaan kapal ikan oleh Kementerian Kelautan dan Perikanan (KKP) merupakan langkah strategis untuk mendorong kesejahteraan nelayan. Realisasi program bantuan kapal perikanan mulai dari tahun 2015 sampai dengan tahun 2018 adalah sebanyak 2.215 unit kapal dengan berbagai tipe dan ukuran yang didistribusikan kepada koperasi nelayan yang tersebar di seluruh Indonesia. Manfaat dari program tersebut adalah peningkatan pendapatan hingga mencapai 200\% karena jangkauan melaut yang lebih luas dan hasil tangkapan lebih banyak. Selain itu, dampak positif juga dirasakan oleh sektor industri galangan kapal ikan yang meningkat serta dibarengi dengan peningkatan daya serap tenaga kerja baru di bidang perkapalan (Kementerian Kelautan dan Perikanan, 2019).

Bantuan kapal perikanan yang dihibahkan KKP kepada kelompok nelayan di berbagai penjuru daerah Indonesia dalam proses pengoperasinya akan mengalami kerusakan sebagaimana yang terjadi pada kapal perikanan KM. Nelayan 2017-572 kapasitas 5 GT di perairan Lombok Selatan. Kapal tersebut mengalami kebocoran serius pada lambung akibat menabrak karang. Kondisi kerusakan lambung kapal semakin parah akibat hantaman gelombang ditambah lagi dengan faktor eksternal dari masyarakat sekitar yang melakukan penjarahan terhadap komponen mesin utama dan penggerak kapal akibat terbengkalai \pm 1 tahun di pesisir pantai karena tidak adanya anggaran untuk kegiatan reparasi kapal pada tahun 2018.

Kegiatan reparasi lambung kapal dan pengadaan mesin utama dan komponen penggerak kapal baru direalisasi pada tahun 2019 oleh Dinas Kelautan dan Perikanan (DKP) kabupaten setempat melalui skema pembiayaan dari Anggaran Pendapatan dan Belanja Daerah (APBD). Gambar dokumentasi reparasi kapal dapat dilihat pada Gambar 1.

Kurangnya data informasi performa kapal
KM. Nelayan 2017-572 kepada nelayan pengguna menjadi faktor utama pemicu kerusakan kapal dikarenakan nelayan tidak mengetahui karakteristik hidrodinamika dan performa kapal perikanan tersebut. Padahal setiap kapal tentunya dirancang memiliki kecepatan dinas dan batas ketinggian gelombang yang aman. Oleh karena itu, sangat penting untuk mengetahui karakteristik performa kapal KM. Nelayan 2017-572 apalagi kapal ini baru saja direparasi sehingga sangat dihindari terjadinya kecelakaan yang sama. Menurut Paska, dkk. (2016) optimasi lambung kapal dapat meningkatkan performa namun perlu menghitung kembali hambatan dan sinkronisasi engine propeller untuk mendapatkan konfigurasi yang optimal.

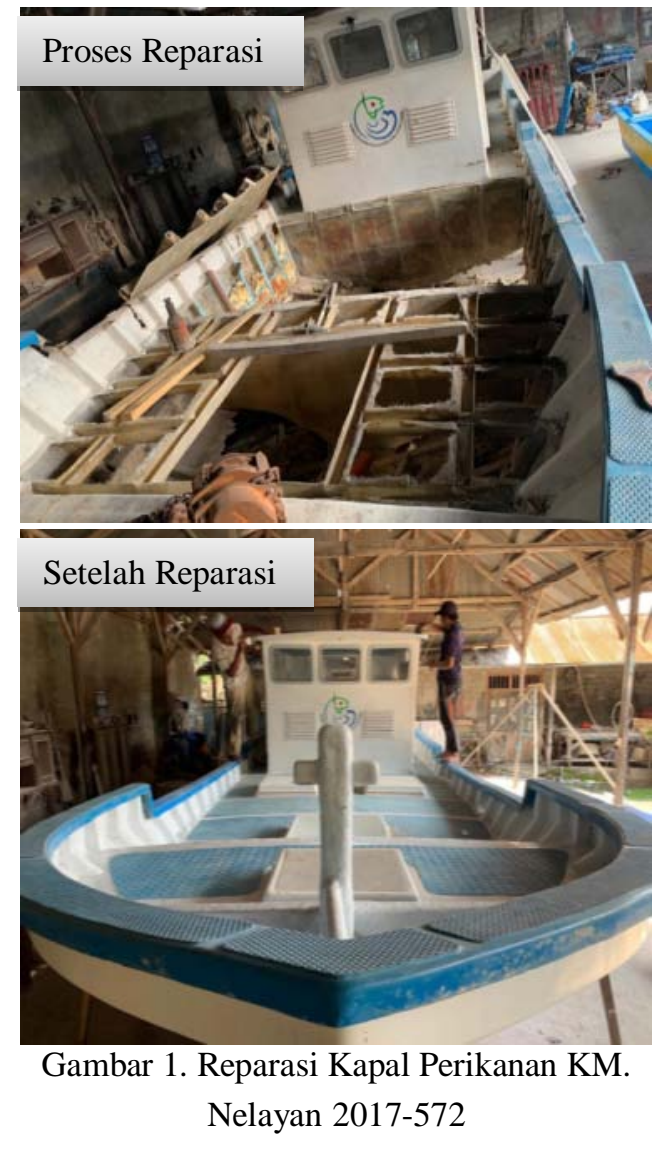

Tujuan dari studi ini adalah mendapatkan titik sinkronisasi (matching) antara mesin utama dengan propeller yang digunakan sehingga diperoleh rentang kecepatan kapal yang dihasilkan akibat penggunaan sistem penggerak kapal baru tersebut. Manfaat dari studi ini adalah diketahuinya nilai sinkronisasi antara mesin dan propeller sehingga 
dengan data tersebut dapat diberikan rekomendasi untuk mengoptimalkan kemampuan sistem penggerak kapal.

Menurut Leksono (2016) sinkronisasi antara lambung kapal, mesin, dan propeller merupakan tahap terpenting dalam penentuan performa suatu kapal. Terdapat kriteria sinkronisasi yang harus dipenuhi sehingga mesin dikatakan mampu memutar propeller di antaranya $\mathrm{Ae} / \mathrm{Ao}_{\text {prop }}$ lebih besar dari $\mathrm{Ae} / \mathrm{Ao}_{\min }$ yang diformulasikan oleh Keller. Selain itu juga harus memenuhi $\mathrm{T}_{\text {prop }} \geq \mathrm{T}_{\text {engine }}$ dan faktor load prop $<$ faktor load mesin.

Faktor load propeller merupakan kebutuhan daya untuk memutar propeller agar menghasilkan thrust sehingga kapal bergerak, sedangkan faktor load mesin adalah ketersediaan daya mesin untuk memutar propeller guna menghasilkan thrust yang dibutuhkan. Pada kasus penelitian ini, kapal telah memiliki mesin utama dan propeller baru. Data performa mesin dapat ditelusuri dari engine maker, begitu pula dengan gearbox-nya. Sedangkan propeller yang digunakan adalah propeller pasaran tipe B-Series seperti terlihat pada Gambar 2, sehingga diperlukan analisa lanjutan untuk mengetahui karakteristik propeller tersebut.

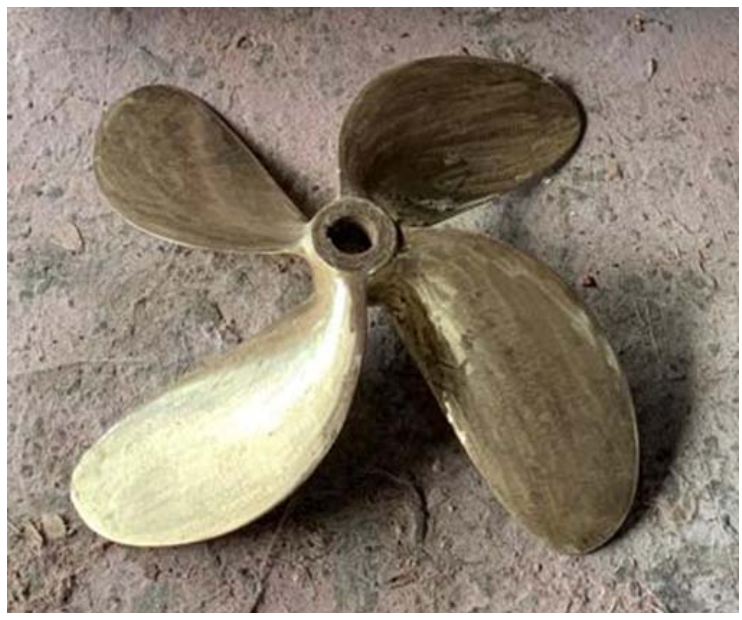

Gambar 2. Propeller kapal tipe B-Series

\section{METODE}

Penelitian diawali dengan melakukan analisa hambatan kapal terhadap variasi kecepatan $\quad 0$ 12 knot karena pada awalnya belum diketahui kecepatan kapal yang dihasilkan oleh kombinasi mesin utama dan komponen sistem penggerak kapal yang baru. Akan tetapi, terdapat hipotesis bahwa kecepatan kapal berada pada rentang 7 - 9 knot berdasarkan data kapal sebelum reparasi. Oleh karena itu, akan didetailkan analisa hambatan pada rentang kecepatan tersebut.

Menurut Holtrop dan Mennen (1982) hambatan kapal dapat diuraikan menjadi beberapa komponen seperti hambatan gesek $\left(\mathrm{R}_{\mathrm{F}}\right)$, hambatan gelombang $\left(\mathrm{R}_{\mathrm{W}}\right)$ yang terdiri dari wave making dan wave breaking resistance, hambatan tekanan tambahan dari bulbous bow dekat permukaan air (RB), hambatan tekanan tambahan dari buritan yang tercelup $\left(\mathrm{R}_{\mathrm{TR}}\right)$, dan hambatan korelasi bentuk kapal $\left(\mathrm{R}_{\mathrm{A}}\right)$.

Formulasi untuk memprediksi hambatan kapal dapat menggunakan metode (Holtrop, Statistical Re-Analysis of Resistance and Propulsion Data, 1984) dengan persamaan (1).

$$
\begin{aligned}
R_{T}= & R_{F}(1+k 1)+R_{A P P}+R_{W}+R_{B}+ \\
& R_{T R}+R_{A}
\end{aligned}
$$

Keterangan:

$\mathrm{R}_{\mathrm{F}} \quad$ : Tahanan gesek berdasarkan formulasi ITTC - 1957;

$1+\mathrm{K}_{1}$ : Faktor bentuk yang menggambarkan tahanan viskositas dari bentuk lambung yang berhubungan dengan $\mathrm{R}_{\mathrm{F}}$;

$\mathrm{R}_{\mathrm{APP}}$ : Tahanan anggota badan;

$\mathrm{R}_{\mathrm{W}}$ : Tahanan gelombang (wave making and wave breaking resistance);

$\mathrm{R}_{\mathrm{B}} \quad$ : Tahanan tekanan tambahan dari bulbous bow dekat permukaan air;

$\mathrm{R}_{\mathrm{TR}}$ : Tahanan tekanan tambahan dari buritan yang tercelup;

$\mathrm{R}_{\mathrm{A}} \quad$ : Tahanan korelasi bentuk kapal.

Selain itu, dapat pula menggunakan metode Harvald (1983) dengan persamaan (2).

$$
R_{T}=\frac{1}{2} C_{T} \rho S v^{2}
$$

$\mathrm{R}_{\mathrm{T}}$ adalah hambatan total kapal, $\mathrm{C}_{\mathrm{T}}$ adalah keofisien hambatan, $\rho$ adalah massa jenis air laut, $S$ adalah luas permukaan lambung bidang basah, dan $v$ adalah kecepatan kapal. 
Kajian Sinkronisasi Mesin Utama dan Propeller pada Kapal Perikanan Pasca Reparasi

(Studi Kasus KM. Nelayan 2017-572)

(Ahmad Yasim, Robertoes Koekoeh Koentjoro Wibowo, dan Kusnindar Priohutomo)

Menurut Yasim, et al. (2019) analisa prediksi hambatan untuk kapal tipe displacement cukup akurat menggunakan metode Holtrop atau metode Compton. Kemudian Leksono (2016) dan Suardi, dkk. (2018) menyebutkan lebih detail bahwa prediksi hambatan kapal ikan lebih akurat jika menggunakan metode Van Oortmersen. Oleh karena itu, dalam penelitian ini dilakukan analisa hambatan dengan membandingkan 3 metode empiris yaitu Holtrop, Van Oortmersen dan Compton. Namun, karena data hasil prediksi semua metode tersebut diperoleh dari software Maxsurf Resistance sehingga dibutuhkan satu analisa hambatan menggunakan perhitungan manual sebagai komparasi. Untuk itu dilakukan perhitungan metod@\&anjattrlya dilakukan perhitungan transmisi daya untuk mendapatkan daya efektif yang digunakan untuk menggerakkan kapal. Perhitungan transmisi daya dilakukan berdasarkan nilai BHP mesin baru yang sebelumnya telah diketahui dari brosur mesin.

Terdapat beberapa turunan horse power dalam menghitung transmisi daya mesin utama kapal ikan antara lain:

- Internal Horse Power (IHP) adalah daya yang ditentukan dari tekanan di dalam silinder atau diperhitungkan dari diagram mesin.

- Brake Horse Power (BHP) adalah daya yang dibutuhkan untuk memutar poros dan nilainya lebih kecil dari IHP karena adanya kehilangan tenaga di dalam silinder.

Dalam BHP dikenal 2 istilah penting yaitu BHPscr dan BHPmcr. BHPscr adalah besarnya daya motor penggerak utama yang dibutuhkan pada pelayaran normal, di mana besarnya adalah 80 - 85\% dari daya keluaran pada kondisi maksimum. Sedangkan BHPmcr adalah daya maksimum yang dibutuhkan mesin untuk mempertahankan kapal pada kecepatan servisnya dikarenakan adanya gangguan seperti gelombang atau angin yang cukup tinggi. Nilai BHPscr dan BHPmcr pada penelitian ini didapatkan dari data mesin yang digunakan.
- Shaft Horse Power (SHP) adalah daya yang dihitung dari torsi pada poros. Persamaan untuk menghitung SHP dapat dilihat pada persamaan (3).

$S H P=B H P_{m c r} \cdot \eta_{g 1} \cdot \eta_{g 2}$

$\eta_{g 1}$ adalah efisiensi single reduction gear yaitu 0.98 dan $\eta_{g 2}$ adalah efisiensi reversing reduction gear yaitu 0,99.

- Delivered Horse Power (DHP) adalah daya yang diserap oleh propeller kapal guna menghasilkan daya dorong (thrust). Persamaan untuk menghitung DHP dapat dilihat pada persamaan (4).

$D H P=S H P \cdot \eta_{\text {transmisi }}$

$\eta_{\text {transmisi }}$ adalah efisiensi poros yaitu 0,98.

- Effective Horse Power (EHP) adalah besarnya daya yang dibutuhkan untuk mengatasi gaya hambat badan kapal (hull) agar kapal dapat bergerak dengan kecepatan servis (vs). Persamaan untuk menghitung EHP dapat dilihat pada persamaan (5) dan (6).

$E H P=R_{T} \cdot V S$

$E H P=D H P \cdot Q p c$

Qpc adalah quasi propulsive coefficient yang dapat dihitung menggunakan persamaan (7).

$Q p c=\eta_{o} \cdot \eta_{\text {hull }} \cdot \eta_{r r}$

$\eta_{o}$ adalah efisiensi propeller yang didapatkan dari pembacaan diagram open water test, $\eta_{r r}$ adalah efisiensi relatif rotatif. Menurut Manen dan Oossanen (1988) S $\eta_{r r}$ memiliki rentang nilai antara 1,0 - 1,1 untuk sistem propulsi single screw. Sedangkan $\eta_{\text {hull }}$ adalah efisiensi bentuk lambung kapal yang dapat dihitung dengan persamaan (8).

$\eta_{\text {hull }}=\frac{1-t}{1-w}$

$t$ adalah thrust deduction factor yang dapat dihitung dengan persamaan (9).

$t=k \cdot w$ 
$k$ adalah konstanta thrust deduction yang memiliki rentang nilai 0,7 -0,9. $w$ adalah wake fraction yang dapat dihitung dengan persamaan (10).

$w=0.5 C b-0.05$

$C b$ adalah koefisien block kapal.

Setelah menghitung rugi transmisi daya, maka selanjutnya melakukan analisa kesesuaian mesin dan propeller atau engine propeller matching.

Menurut Habibi dan Nurhadi (2016) mengolah data hasil pembacaan diagram open water test dapat menggunakan persamaan $K_{T}-\mathrm{J}$ pada persamaan (11), (12) dan (13).

$$
\begin{aligned}
& K_{T}=K \cdot J^{2} \\
& K=\frac{R_{T}}{(1-t) \rho D p^{2} V a^{2}} \\
& K_{T}=\frac{R_{T}}{(1-t) \rho D p^{2} V a^{2}}
\end{aligned}
$$

$K_{T}$ adalah koefisien thrust, Jadalah koefisien air masuk, $D p$ adalah diameter propeller, $t$ adalah thrust deduction factor, dan $V a$ adalah kecepatan air masuk.

Putaran propeller $(n)$ diperoleh dari membagi putaran mesin dengan rasio gear box yang digunakan. Setelah itu thrust, torsi, daya yang diterima propeller menggunakan persamaan (14), (15), (16) dan (17) menurut Manen and Oossanen (1988).

$$
\begin{aligned}
& T_{\text {prop }}=K_{T} \cdot \rho \cdot n^{2} \cdot D p^{4} \\
& T_{\text {engine }}=R_{T} /(1-t) \\
& Q_{\text {prop }}=K_{Q} \cdot \rho \cdot n^{2} \cdot D p^{5} \\
& P d=2 \pi \cdot Q \cdot n
\end{aligned}
$$

Untuk mengetahui faktor beban mesin dan faktor beban propeller dapat menggunakan persamaan (18) (Leksono, 2016).

$$
\frac{K_{Q}}{J^{5}}=\frac{Q_{\text {prop }}}{\rho . V a^{5}}<\frac{P d \cdot n^{2}}{2 \pi \rho V a^{2}}
$$

$K_{Q}$ adalah koefisien torsi, $n$ adalah putaran propeller, $P d$ adalah daya yang diterima propeller, $Q$ adalah torsi, dan $T$ adalah gaya dorong (thrust).

Pada tahap akhir penelitian, dilakukan optimasi sebagai rekomendasi untuk mengoptimalkan potensi kemampuan komponen sistem propulsi baru. Alur penelitian secara singkat dapat dilihat pada Gambar 3.

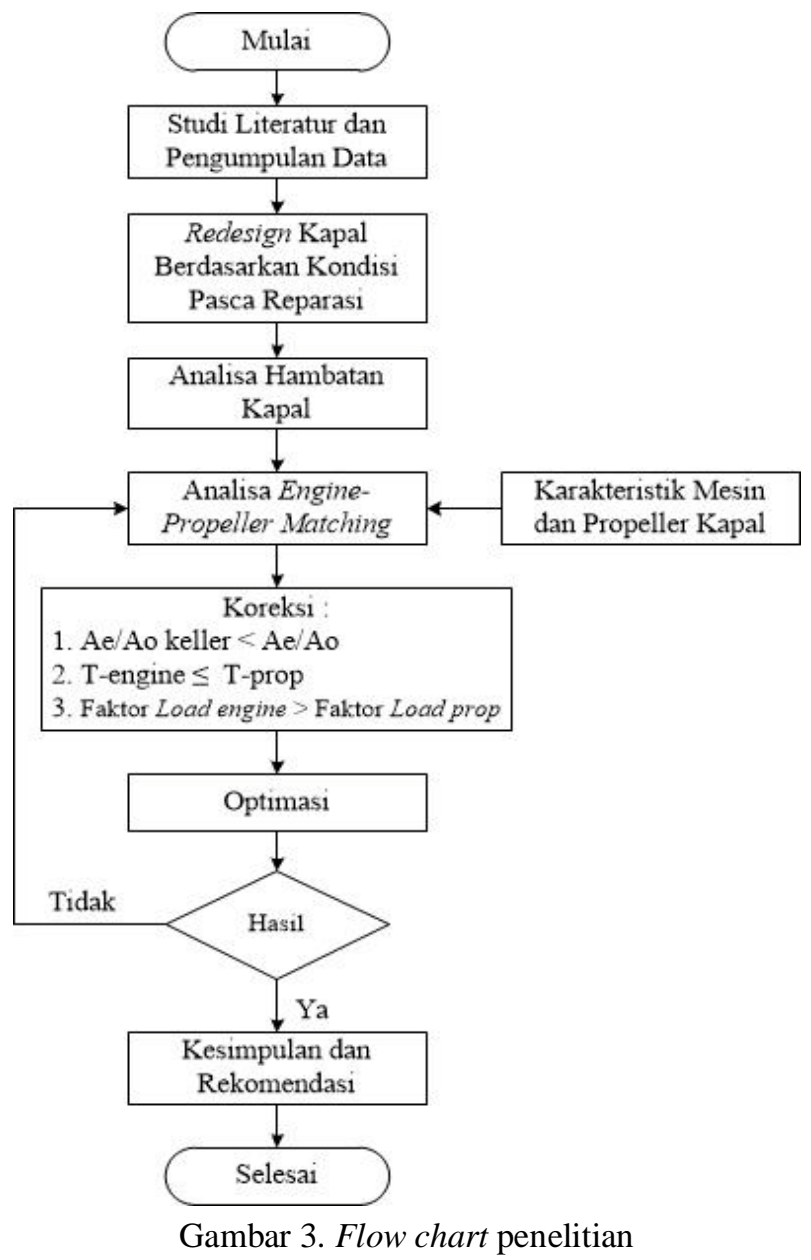

\section{HASIL DAN PEMBAHASAN}

\section{Data Kapal}

1. Ukuran Utama

Panjang seluruh (LoA) : $11,00 \quad \mathrm{~m}$

Panjang garis air (Lwl) : 10,16 m

Lebar seluruh (B) : $\quad 2,60 \mathrm{~m}$

Lebar molded (Bmld) : $\quad 2,50 \quad \mathrm{~m}$

Tinggi geladak $(\mathrm{H}) \quad$ : $\quad 0,95 \mathrm{~m}$

Sarat kapal (T) : $\quad 0,60 \quad \mathrm{~m}$

2. Mesin Utama \& Gear Box

Merek mesin : Dong Feng 
Kajian Sinkronisasi Mesin Utama dan Propeller pada Kapal Perikanan Pasca Reparasi

(Studi Kasus KM. Nelayan 2017-572)

(Ahmad Yasim, Robertoes Koekoeh Koentjoro Wibowo, dan Kusnindar Priohutomo)

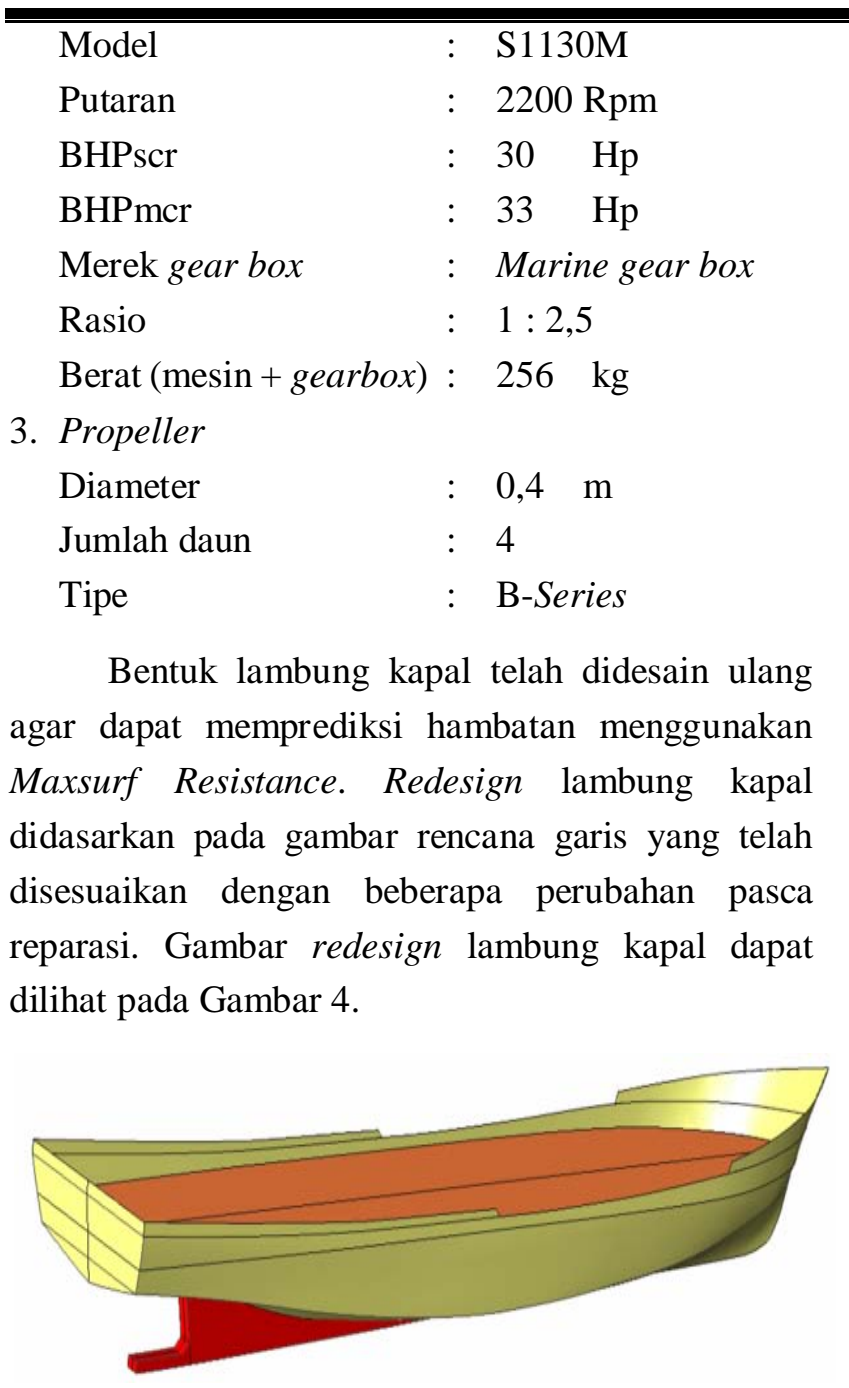

Gambar 4. Redesign lambung kapal KM. Nelayan 2017-572 pasca reparasi

\section{Analisa Hambatan Kapal}

Prediksi hambatan kapal dalam penelitian ini menggunakan 3 metode empiris yang diperoleh dari analisa menggunakan Maxsurf Resistance (Holtop, Compton dan Van Oortmersen) dan satu buah metode empiris yang diperoleh dari hasil perhitungan secara manual (Harvald). Hasil prediksi hambatan kapal ditampilkan pada Gambar 5.

Pada Gambar 5 terlihat bahwa grafik hambatan dari 4 metode yang digunakan telah memiliki tren grafik yang sama dengan galat yang kecil khususnya pada kecepatan di bawah 9 knot. Dengan demikian, hasil prediksi hambatan kapal dinilai cukup baik. Kemudian, dilakukan analisa running free surfaces untuk melihat pola gelombang yang terjadi pada lambung kapal ketika berlayar pada kecepatan sekitar 7 knot sebagaimana dapat diperhatikan pada Gambar 6.

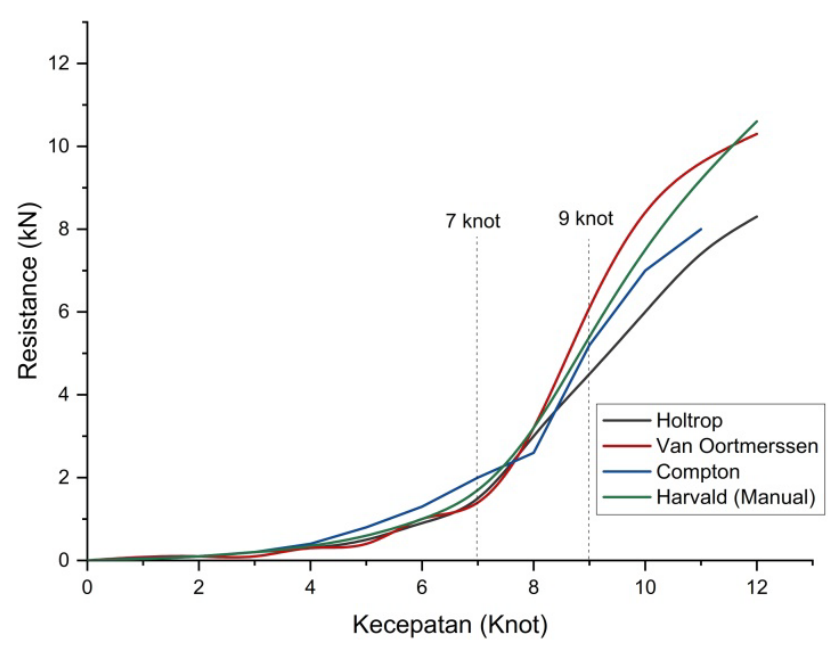

Gambar 5. Grafik hasil prediksi hambatan kapal

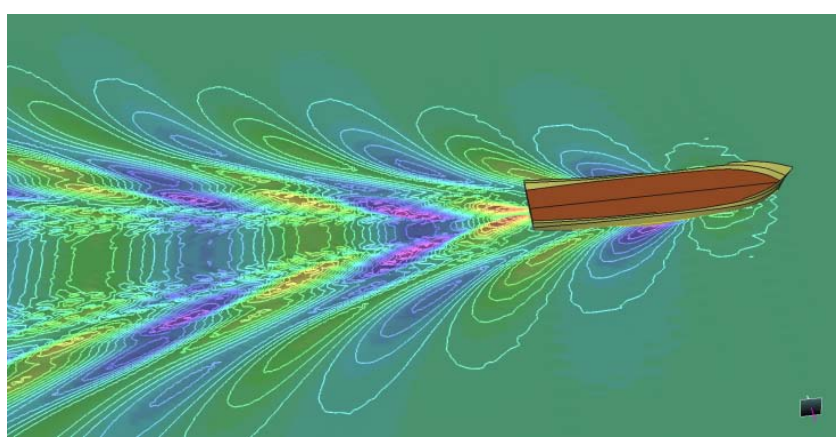

Gambar 6. Pola gelombang yang terjadi saat kapal bergerak pada kecepatan 7 knot

Analisa hambatan kapal perikanan pada Gambar 5 merupakan tahap awal untuk memprediksi besarnya hambatan kapal yang terjadi pada kapal KM. Nelayan 2017-572 setelah reparasi dan penggantian komponen penggerak kapal. Berdasarkan data operasional kapal sebelum insiden, diketahui kecepatan kapal adalah berkisar 7 - 9 knot, sehingga untuk memprediksi hambatan dan kecepatan kapal pasca reparasi maka diberikan Tabel 1 yang menyajikan secara detail nilai hambatan dan kecepatan kapal pada rentang 7 - 9 knot.

Hasil analisa hambatan pada Tabel 1 kemudian menjadi dasar penentuan nilai prediksi hambatan dan kecepatan kapal perikanan berdasarkan EHP yang didapatkan dari analisa engine propeller matching yang diawali dengan perhitungan rugi transmisi daya. 
Tabel 1. Hasil analisa hambatan kapal pada rentang kecepatan $7-9$ knot

\begin{tabular}{|c|c|c|c|c|}
\hline \multirow{2}{*}{$\begin{array}{c}v \\
\text { (knot) }\end{array}$} & \multicolumn{2}{|c|}{ Holtrop } & \multicolumn{2}{|c|}{ Van Oortmerssen } \\
\hline & $\begin{array}{c}\mathrm{RT} \\
(\mathrm{kN})\end{array}$ & $\begin{array}{l}\text { EHP } \\
(\mathrm{kW})\end{array}$ & $\begin{array}{c}\mathrm{RT} \\
(\mathrm{kN})\end{array}$ & $\begin{array}{l}\text { EHP } \\
(\mathrm{kW})\end{array}$ \\
\hline 7,00 & 1,50 & 5,40 & 1,40 & 5,02 \\
\hline 7,10 & 1,60 & 5,84 & 1,50 & 5,37 \\
\hline 7,20 & 1,70 & 6,33 & 1,60 & 5,80 \\
\hline 7,30 & 1,80 & 6,89 & 1,70 & 6,31 \\
\hline 7,40 & 2,00 & 7,51 & 1,80 & 6,96 \\
\hline 7,50 & 2,10 & 8,22 & 2,00 & 7,72 \\
\hline 7,60 & 2,30 & 9,01 & 2,20 & 8,57 \\
\hline 7,70 & 2,50 & 9,90 & 2,40 & 9,54 \\
\hline 7,80 & 2,70 & 10,79 & 2,60 & 10,62 \\
\hline 7,90 & 2,80 & 11,56 & 2,90 & 11,79 \\
\hline 8,00 & 3,00 & 12,34 & 3,20 & 13,06 \\
\hline 8,10 & 3,20 & 13,14 & 3,50 & 14,42 \\
\hline 8,20 & 3,30 & 13,96 & 3,80 & 15,85 \\
\hline 8,30 & 3,50 & 14,79 & 4,10 & 17,34 \\
\hline 8,40 & 3,60 & 15,65 & 4,40 & 18,88 \\
\hline 8,50 & 3,80 & 16,51 & 4,70 & 20,47 \\
\hline 8,60 & 3,90 & 17,40 & 5,00 & 22,09 \\
\hline 8,70 & 4,10 & 18,30 & 5,30 & 23,73 \\
\hline 8,80 & 4,20 & 19,22 & 5,60 & 25,38 \\
\hline 8,90 & 4,40 & 20,16 & 5,90 & 27,04 \\
\hline 9,00 & 4,60 & 21,12 & 6,20 & 28,69 \\
\hline
\end{tabular}

\section{Analisa Engine propeller Matching}

Menghitung SHP berdasarkan nilai BHPscr mesin menggunakan persamaan (3).

$$
\begin{aligned}
\text { SHP } & =30 \mathrm{Hp} \times 0,98 \times 0,99 \\
& =29,11 \mathrm{Hp} \text { atau } 21,70 \mathrm{~kW}
\end{aligned}
$$

Menghitung DHP berdasarkan nilai SHP menggunakan persamaan (4).

$$
\begin{aligned}
D H P & =29,11 \mathrm{Hp} \times 0,98 \\
& =28,52 \mathrm{Hp} \text { atau } 21,27 \mathrm{~kW}
\end{aligned}
$$

Untuk menghitung EHP dibutuhkan nilai Qpc yang dapat dihitung menggunakan persamaan (7) dan juga membutuhkan nilai $\eta_{r r}$ (diambil nilai ketentuan $=1$ ); $\eta_{\text {hull }}$ didapatkan dari kalkulasi persamaan (8) dan turunannya yaitu persamaan (9) dan (10).

$$
\begin{aligned}
& \begin{aligned}
w & =0,5(0,5)-0,05 \\
& =0,20 \\
t & =0,7(0,2) \\
& =0,14
\end{aligned} \\
& \eta_{\text {hull }}=\frac{1-0,14}{1-0,20} \\
& =1.08
\end{aligned}
$$

Sedangkan $\eta_{o}$ diperoleh dari karakteristik propeller. Dari hasil analisa diketahui nilai P/D propeller 1,2 dan Ae/Ao 0,55. Kemudian dilakukan pembacaan diagram open water B4-55 menggunakan persamaan garis KT-J (lihat persamaan (13)).

$$
\begin{aligned}
K_{T} & =\frac{1,70 k N^{*}}{(1-0,14)(1,025)(0,4)^{2}(3)^{2}} J^{2} \\
& =1,34 J^{2}
\end{aligned}
$$

Nilai $\mathrm{R}_{\mathrm{T}}=1.70 \mathrm{kN}$ dan $\mathrm{Va}=3 \mathrm{~m} / \mathrm{s}$ diperoleh dari proses iterasi berdasarkan data hasil analisa hambatan kapal, Tabel 1 pada Vs 7,3 knot (metode Van Oortmerssen).

Plotting persamaan garis KT-J pada diagram open water B4-55 ditampilkan pada Gambar 7. Pada gambar tersebut dapat diketahui pada kondisi sea trial propeller memiliki karakteristik $\mathrm{J}=0,51$; $\mathrm{K}_{\mathrm{T}}=0,35 ; \mathrm{K}_{\mathrm{Q}}=0,062$ dan $\eta_{o}=0,45$, sehingga dapat dihitung nilai $Q p c$ menggunakan persamaan (7).

$$
\begin{aligned}
Q p c & =0,45 \times 1,08 \times 1,00 \\
& =0,49
\end{aligned}
$$

Selanjutnya thrust, torsi dan power delivery juga dapat dihitung menggunakan persamaan (14), (15), (16) dan (17). 
Kajian Sinkronisasi Mesin Utama dan Propeller pada Kapal Perikanan Pasca Reparasi

(Studi Kasus KM. Nelayan 2017-572)

(Ahmad Yasim, Robertoes Koekoeh Koentjoro Wibowo, dan Kusnindar Priohutomo)

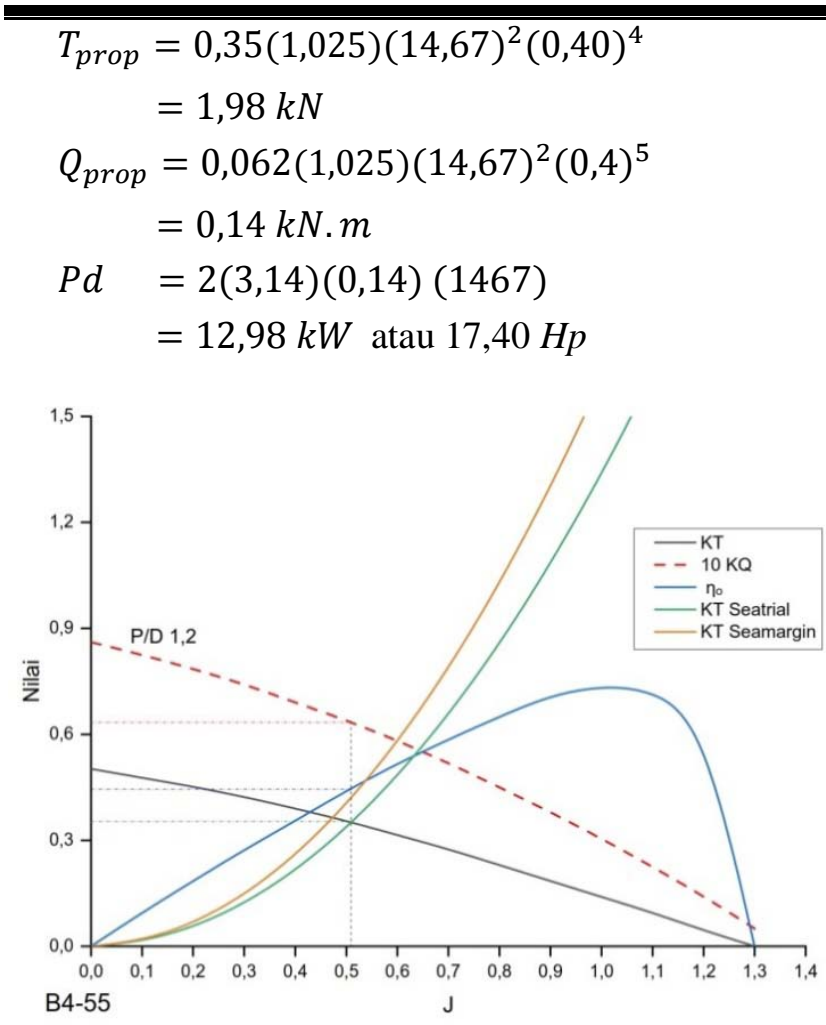

Gambar 7. Pembacaan diagram open water berdasarkan kondisi KT sea trial

Power delivery (Pd) adalah daya yang diterima propeller untuk menghasilkan thrust. Oleh karena itu, $P d$ menjadi dasar untuk mengetahui nilai EHP yang dihasilkan sistem propulsi yang terpasang pada Kapal Perikanan 5 GT tersebut.

$$
\begin{aligned}
E H P & =P d \times Q p c \\
& =12,98 \mathrm{~kW} \times 0,49 \\
& =6,31 \mathrm{~kW} \text { atau } 8,46 \mathrm{Hp}
\end{aligned}
$$

Nilai EHP tersebut dicek pada Tabel 1 metode Van Oortmerssen dan diketahui bahwa kapal ikan tersebut memiliki kecepatan dinas Vs berkisar pada 7,3 knot. Nilai tersebut sudah sesuai dengan nilai input saat menghitung persamaan garis KT-J.

\section{Koreksi Engine propeller Matching}

Perlu dicek apakah mesin dan propeller yang terpasang di kapal sudah memenuhi kriteria engine propeller matching sebagaimana dijelaskan di bagian pendahuluan. Untuk itu, dibutuhkan nilai $\mathrm{T}_{\text {engine }}$ yang dapat dihitung menggunakan persamaan (15).

$$
\begin{aligned}
T_{\text {engine }} & =\frac{1.70 \mathrm{kN}}{(1-0,14)} \\
& =1,98 \mathrm{kN}
\end{aligned}
$$

$\mathrm{Ae} / \mathrm{Ao}_{\min }$ sebelumnya telah dihitung menggunakan persamaan (19).

$$
\frac{A e}{A o} \min =\frac{1.3+0.3 * Z * T}{(P o-P v) D p^{2}}+K
$$

$\mathrm{Z}$ adalah jumlah daun propeller, $\mathrm{T}$ adalah thrust engine, Po-Pv adalah tekanan pada poros propeller yang nilainya adalah 99,6 - 10,05 h dengan $\mathrm{h}$ adalah ketinggian poros propeller, $\mathrm{K}$ adalah konstanta untuk single screw yaitu 0,2.

$$
\begin{aligned}
\frac{A e}{A o} \min & =\frac{1,3+0,3 * 4 * 1,98}{(97,59)(0,4)^{2}}+0,2 \\
& =0,44
\end{aligned}
$$

Dari perbandingan nilai $\mathrm{T}$ diketahui bahwa $T_{\text {engine }}=T_{\text {prop }}$ yaitu $1,98 \mathrm{kN}$ (memenuhi syarat). Kemudian perbandingan nilai Ae/Ao diketahui bahwa $\mathrm{Ae} / \mathrm{Ao}_{\min }<\mathrm{Ae} / \mathrm{Ao}_{\text {prop }}$ yaitu $0,44<0,55$ (memenuhi syarat). Selanjutnya mengecek faktor load mesin dan propeller yang harus memenuhi persamaan (18).

$$
\begin{aligned}
& \frac{K_{Q}}{J^{5}}=\frac{Q_{\text {prop }}}{\rho . V a^{5}}<\frac{D H P \cdot n^{2}}{2 \pi \rho V a^{2}} \\
& \frac{0,062}{(0,51)^{5}}=\frac{0,14}{(1,025)(3)^{5}}<\frac{21,27(14,67)^{2}}{2(3,14)(1,025)(3)^{2}} \\
& 1,77=1,77<2,91 \quad \text { (memenuhi syarat) }
\end{aligned}
$$

Dengan demikian diketahui bahwa mesin dan sistem propulsi baru yang terpasang pada kapal pasca reparasi telah memenuhi syarat mesin dan propeller yang sinkron. Artinya bahwa mesin yang digunakan dapat memutar propeller sehingga propeller dapat bekerja menghasilkan thrust untuk mendorong kapal. Grafik engine propeller matching dapat diperhatikan pada Gambar 8.

Sinkronisasi antara mesin utama dan sistem penggerak yang ada pada kapal pasca reparasi belum pada titik optimal. Terlihat bahwa kinerja maksimal propeller hanya membutuhkan daya mesin (power delivery) sebesar 60\%. Oleh karena itu, diperlukan optimasi engine propeller matching sebagai upaya meningkatkan sinkronisasi mesin utama dan sistem penggerak sehingga kecepatan 
kapal bertambah.

\section{Optimasi Engine Propeller Matching}

Terdapat beberapa cara untuk mengoptimalkan sinkronisasi mesin utama dan sistem penggerak tetapi karena dalam kasus ini adalah Kapal Ikan 5 GT maka yang paling efektif adalah mengubah rasio gearbox. Adapun, perencanaan propeller baru tidak dilakukan karena nantinya harus membuat propeller custom sehingga membutuhkan biaya yang besar.

Dari hasil studi optimasi, dipilih rasio gearbox $1: 2,2$ sehingga putaran propeller menjadi 1000 rpm. Perubahan putaran propeller secara signifikan dapat meningkatkan power delivery (DHP) propeller seperti ditunjukkan pada Gambar 8.

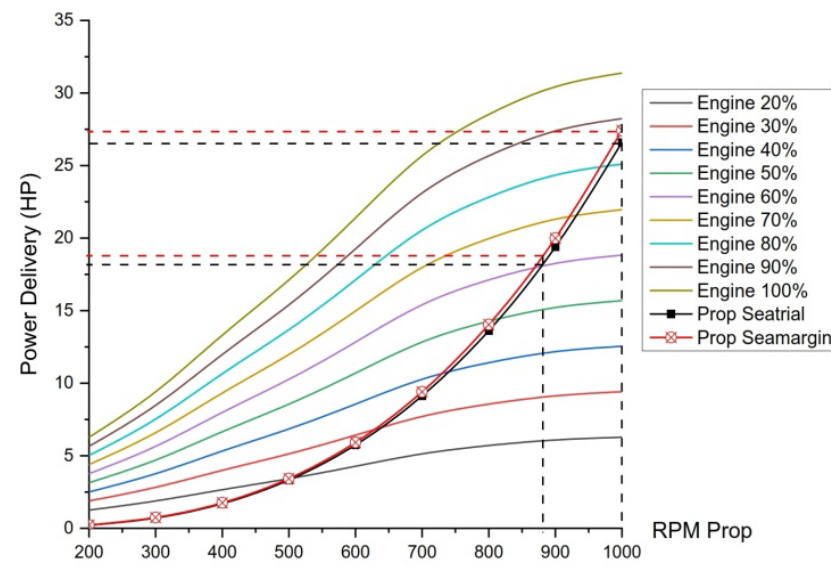

Gambar 8. Grafik engine propeller matching pasca reparasi dan perubahan rasio gearbox

Selain itu, perubahan rasio gearbox masih memenuhi kriteria engine propeller matching. Hal ini karena nilai $T_{\text {engine }} 1,98 \mathrm{kN}<T_{\text {prop }} 2,70 \mathrm{kN}$ dan faktor load mesin dan propeller masih memenuhi persamaan (18).

$$
\begin{aligned}
& \frac{0,065}{(0,48)^{5}}=\frac{0,19}{(1,025)(3,2)^{5}}<\frac{21,27(16,67)^{2}}{2(3,14)(1,025)(3,2)^{2}} \\
& 2,68=2,68<2,91
\end{aligned}
$$

Akan tetapi, DHP yang diterima propeller tidak dikonversi maksimal menjadi effective power (EHP) akibat penurunan efisiensi, $\eta_{o}$ dari 0,45 menjadi 0,42 karena peningkatan putaran propeller dari $880 \mathrm{rpm}$ menjadi $1000 \mathrm{rpm}$. EHP yang dihasilkan adalah 9,6 kW, sehingga meskipun mesin bekerja lebih berat (performa mesin dari 60\% bmep menjadi 85\% bmep), namun kecepatan kapal hanya meningkat 0,41 knot (dari 7,3 knot menjadi 7,71 knot) berdasarkan grafik hubungan kecepatan kapal dengan RPM propeller pada Gambar 9. Dengan demikian, dinilai lebih baik jika tetap menggunakan kombinasi mesin dan sistem penggerak yang ada pada kapal saat ini.

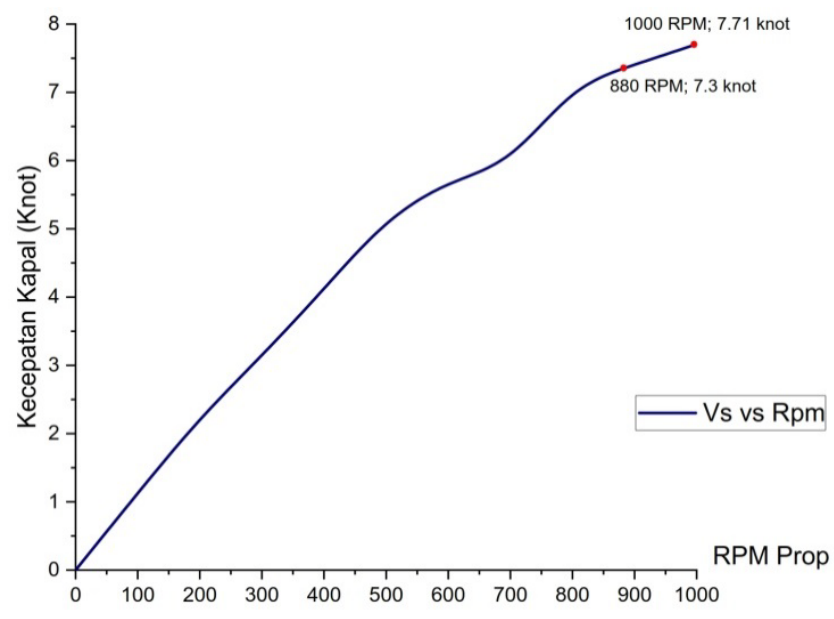

Gambar 9. Grafik hubungan kecepatan kapal dengan RPM propeller

\section{KESIMPULAN}

Berdasarkan hasil studi, diketahui bahwa mesin utama dan propeller Kapal Perikanan 5 GT pasca reparasi telah memenuhi kriteria engine propeller matching. Hal ini karena syarat nilai $\mathrm{Ae} / \mathrm{Ao}_{\text {prop }}>\mathrm{Ae} / \mathrm{Ao}_{\min }$ (Keller), $\mathrm{T}_{\text {prop }} \geq \mathrm{T}_{\text {engine }}$ dan faktor load propeller $<$ faktor load mesin terpenuhi. Sinkronisasi mesin dan propeller kapal pasca reparasi menghasilkan kecepatan kapal 7,3 knot sehingga diklaim kecepatan desain sudah tercapai yaitu 7 - 9 knot. Sinkronisasi mesin dan propeller kapal masih dapat dioptimasi dengan mengubah gearbox. Jika mengubah rasio gearbox menjadi $1: 2,2$, kecepatan kapal dapat ditingkatkan menjadi 7,7 knot. Namun, mempertimbangkan biaya penggantian gearbox dan di samping itu kecepatan kapal yang hanya bertambah 0,4 knot maka, lebih baik jika tetap menggunakan kombinasi mesin dan sistem penggerak yang ada pada kapal saat ini. Selain itu, mesin lebih hemat bahan bakar karena 
Kajian Sinkronisasi Mesin Utama dan Propeller pada Kapal Perikanan Pasca Reparasi

(Studi Kasus KM. Nelayan 2017-572)

(Ahmad Yasim, Robertoes Koekoeh Koentjoro Wibowo, dan Kusnindar Priohutomo)

bekerja di bawah kondisi SCR (60\% bmep).

\section{UCAPAN TERIMA KASIH}

Ungkapan terima kasih yang sebesar-besarnya kepada Rektor Universitas Jember dan Ketua LPPM yang telah membantu pendanaan penelitian, dan juga kepada Dekan Fakultas Teknik Universitas Jember, Kaprodi Teknik Konstruksi Perkapalan atas dukungan fasilitas pelaksanaan penelitian.

\section{DAFTAR PUSTAKA}

Habibi, \& Nurhadi. (2016). Analisa Pemilihan Propeller Tipe B-Series pada Kapal Feri Ro-Ro 600 GT dengan Menggunakan Aplikasi Matchpro. Jurnal Wave, Vol. 9(2), 75-81.

Harvald, S. A. (1983). Resistance and Propulsion of Ships. New York: John Wiley \& Sons.

Holtrop, J. (1984). Statistical Re-Analysis of Resistance and Propulsion Data. International Shipbuilding Progress, Vol. 31(363), 272-276.

Holtrop, J., \& Mennen, G. G. (1982). An Approximate Power Prediction Method. International Shipbuilding Progress, Vol. 29(335), 166-170.

Kementerian Kelautan dan Perikanan. (2019). Realisasi Investasi Sektor Kelautan dan Perikanan. Retrieved from Direktorat
Jenderal Penguatan Daya Saing Produk Kelautan dan Perikanan: https://kkp.go.id/djpdspkp/page/2202-realis asi-investasi-sektor-kelautan-dan-perikanan. Leksono, S. (2016). Sinkronisasi Propeller dengan Mesin Induk pada Kapal Ikan untuk Meningkatkan Efisiensi dan Kinerja. Jurnal Wave, Vol. 10 (1), 19-24.

Manen, J. V., \& Oossanen, P. V. (1988). Propulsion. In E. V. Lewis (Ed.), Principles of Naval Architecture (pp. 127-240). Jersey City: The Society of Naval Architects and Marine Engineers.

Paska, A., Hadi, E. S., \& Kiryanto. (2016). Analisa Engine Propeller Matching pada Kapal Perintis Baru Type 200 DWT untuk Medapatkan Sistem Propulsi yang Optimal. Jurnal Teknik Perkapalan, Vol. 4(3), 576-585.

Suardi, Setiawan, W., Ikhwani, R. J., \& Salma, H. D. (2018). Desain Kapal Penangkap Ikan Multipurpose 70 GT. Jurnal Inovtek Polbeng, 8(2), 175-180.

Yasim, A., Widodo, Ali, B., \& Ghofur, A. (2019). On the Comparison of Resistance Prediction for BPPT's Design of Offshore Platform Decommissioning Vessel using Numerical, Experimental and Empirical Methods. Surabaya: Institut Teknologi Sepuluh Nopember. 